\title{
Severe diabetes and leptin resistance cause differential hepatic and renal transporter expression in mice
}

\author{
Vijay R More', Xia Wen², Paul E Thomas ${ }^{3}$, Lauren M Aleksunes ${ }^{2}$ and Angela L Slitt ${ }^{*}$
}

\begin{abstract}
Background: Type-2 Diabetes is a major health concern in the United States and other Westernized countries, with prevalence increasing yearly. There is a need to better model and predict adverse drug reactions, drug-induced liver injury, and drug efficacy in this population. Because transporters significantly contribute to drug clearance and disposition, it is highly significant to determine whether a severe diabetes phenotype alters drug transporter expression, and whether diabetic mouse models have altered disposition of acetaminophen (APAP) metabolites.

Results: Transporter mRNA and protein expression were quantified in livers and kidneys of adult C57BKS and db/db mice, which have a severe diabetes phenotype due to a lack of a functional leptin receptor. The urinary excretion of acetaminophen-glucuronide, a substrate for multidrug resistance-associated proteins transporters was also determined. The mRNA expression of major uptake transporters, such as organic anion transporting polypeptide Slco1a1 in liver and kidney, 1a4 in liver, and Slc22a7 in kidney was decreased in db/db mice. In contrast, Abcc3 and 4 mRNA and protein expression was more than 2 fold higher in $\mathrm{db} / \mathrm{db}$ male mouse livers as compared to C57BKS controls. Urine levels of APAP-glucuronide, -sulfate, and N-acetyl cysteine metabolites were higher in $\mathrm{db} / \mathrm{db}$ mice.
\end{abstract}

Conclusion: A severe diabetes phenotype/presentation significantly altered drug transporter expression in liver and kidney, which corresponded with urinary APAP metabolite levels.

Keywords: Leptin, Diabetes, Transporters, Disposition, Acetaminophen

\section{Background}

The prevalence of obesity and metabolic syndrome has increased at an alarming rate. By the year 2030, the number of adults with either type- 1 or type- 2 diabetes is estimated to be greater than 350 million [1]. Adult onset type- 2 diabetes (T2DM) constitutes over $90 \%$ of all diabetes cases and is characterized by insulin resistance, abnormal insulin secretion, or both. Of these cases, it is estimated that $16 \%$ of people have undiagnosed or poorly managed diabetes (NIDDK National Health Interview survey, 2007-2009).

It is well documented that Type- 2 diabetes and hepatic steatosis are co-present [2]. The incidence of non-alcoholic fatty liver disease (NAFLD) is prevalent in 40 to $70 \%$ of patients with T2DM $[3,4]$. This type of liver disease originates as hepatic steatosis, and can progress to non-

\footnotetext{
*Correspondence: aslitt@uri.edu

'Department of Biomedical and Pharmaceutical Sciences, University of Rhode Island, Kingston, RI 02881, USA

Full list of author information is available at the end of the article
}

alcoholic steatohepatitis (NASH), cirrhosis, and end stage liver failure [5]. T2DM-related NAFLD is not fully understood, but it is known that leptin and insulin are important mediators in the progression of NAFLD [6]. Leptin is a hormone secreted by adipocytes, which binds to the leptin receptor and increases partitioning of fatty acids towards oxidation instead of triacylglycerol formation [7]. In mice and rats, leptin deficiency causes hyperphagia and obesity [8]. Moreover, the lack of leptin action causes increased insulin secretion, which is hypothesized to cause insulin resistance in rodents and humans [9]. Insulin resistance syndrome is hypothesized to cause NAFLD and augment progression to NASH [10].

T2DM and hepatic steatosis are modeled by a variety of diet and genetically modified rodent models. $\mathrm{Db} / \mathrm{db}$ mice (BKS.Cg-m +/+ Leprdb/J) mice possess a spontaneous diabetes $(\mathrm{Db})$ mutation in the leptin receptor. $\mathrm{Db} /$ $\mathrm{db}$ mice are insulin resistant, hyperinsulinemic, hyperglycemic, glucose intolerant, and possess abnormal islet cell 
morphology [11-13]. They become hyperinsulinemic from 10-14 days after birth; and exhibit significant weight gain with abnormally high triglycerides and lowand very low-density lipoproteins at 3 to 4 weeks of age. Hyperglycemia appears after 4-6 weeks of age.

Other mouse models of obesity, diabetes, and NAFLD exhibit altered transporter expression in liver and kidney [14]. Transporters are membrane proteins, which facilitate chemical transport into and out of cells [15]. Organic anion transporting polypeptides, organic anion transporters and organic cation transporters are often referred to as "uptake transporters". They are predominantly localized to the basolateral membrane and extract chemicals from blood into hepatocytes (as reviewed by $[15,16]$, but it should be noted that Oatps are localized to the luminal membrane in kidney [17]. Transporters that are members of the ATP-binding cassette (Abc) superfamily facilitate efflux of chemicals out of cells; and include Multidrug resistance proteins (Abcbs), Multidrug resistance-associated proteins (Abcc), Bile salt-export pump (Abcb11), and Breast cancer resistance protein (Abcg2). In liver, Abcc2, Abcg2 and Abcbs are localized to the canalicular membrane and facilitate biliary excretion of chemicals. Abcc1, 3-6 are localized sinusoidally and/or basolaterally, and efflux chemicals from hepatocytes into blood. In kidney, organic anion and cation transporters contribute to renal clearance, along with organic anion transporting polypeptides and Abcc transporters for determining the urinary excretion of many endogenous chemicals and xenobiotics.

There is evidence in rodents and humans that obesity, NAFLD, and NASH may increase susceptibility to druginduced liver disease (DILI) [18] and exhibit altered excretion of acetaminophen [19]. Early studies demonstrated that obese overfed rats, which display NAFLD, were more sensitive to acetaminophen (APAP)-induced liver toxicity [18]. Other studies have demonstrated that obese rats exhibited increased furosemide-induced renal and hepatic toxicity [20], as well as gentamicin-induced nephrotoxicity [21]. More recently, studies documented higher serum and urinary levels of APAP glucuronide (APAP-G) in children with NAFLD, as compared to controls, after a single dose of APAP [22].
Because obese and diabetic people comprise a significant portion of the population within the United States, there is a growing need to better predict drug clearance, DILI, adverse drug effects, and drug efficacy in this population. As transporters comprise a significant mechanism by which multiple drugs undergo hepatic and renal clearance, it is imperative to determine whether diabetes affects transporter expression. The purpose of this study was to compare drug transporter expression levels in normal and diabetic mice and illustrate that the disposition of a prototypical Abcc substrate is altered. The study herein thoroughly characterizes drug transporter expression in the $\mathrm{db} / \mathrm{db}$ model, which can provide guidance for disposition/ toxicology studies in diabetics. In the present study, transporter mRNA and protein expression was markedly changed in $\mathrm{db} / \mathrm{db}$ mice, which exhibit a severe diabetes phenotype and NAFLD. Moreover increased excretion of APAP metabolites into urine was observed in $\mathrm{db} / \mathrm{db}$ mice.

\section{Results}

Tissue and body weights, blood glucose levels, and liver histopathologic evaluation in C57BKS and $\mathrm{db} / \mathrm{db}$ mice

Table 1 illustrates the body weights, liver and kidney weights and blood glucose levels of C57BKS and $\mathrm{db} / \mathrm{db}$ mice at 9 weeks of age. Body weights for $\mathrm{db} / \mathrm{db}$ mice were 1.7 and 2.1 times higher than C57BKS males and females, respectively. $\mathrm{Db} / \mathrm{db}$ male and female mice had liver weights that were 1.8 and 2.1 times greater than those of C57BKS mice, respectively. At nine weeks of age, blood glucose levels in $\mathrm{db} / \mathrm{db}$ mice were elevated about 3-fold.

Histopathological analysis showed mild to moderate steatosis in male and female $\mathrm{db} / \mathrm{db}$ mice (Additional file 1 : Figure S1). Both male and female $\mathrm{db} / \mathrm{db}$ mice exhibited centrilobular and midzonal hepatocyte microvesicular vacuolation. Livers of C57BKS mice appeared normal without vacuolations.

\section{$\mathrm{Db} / \mathrm{db}$ mice exhibit altered uptake transporter mRNA and protein expression in liver}

Solute carrier proteins are predominantly localized to the basolateral membrane of hepatocytes and transport chemicals into the hepatocytes and are generally referred to as uptake transporters. Slcola1 expression was higher in male

Table 1 Body, liver and kidney weight and blood glucose levels for $\mathrm{db} / \mathrm{db}$ and C57BKS control mice ${ }^{\mathrm{a}}$

\begin{tabular}{ccccccc}
\hline Strain & Gender & Liver Weight $(\mathbf{g})$ & Kidney weight $\mathbf{( g )}$ & Average body weight (g) & Liver/Body weight & Mean blood glucose levels(mg/dL) \\
\hline C57BKS & Female & $0.89 \pm 0.03$ & $0.25 \pm 0.00$ & $17.75 \pm 0.23$ & $0.050 \pm 0.001$ & $156 \pm 3$ \\
& Male & $1.00 \pm 0.02$ & $0.31 \pm 0.02$ & $21.89 \pm 0.35$ & $0.046 \pm 0.001$ & $158 \pm 9$ \\
$\mathrm{Db} / \mathrm{db}$ & Female & $1.88 \pm 0.08^{*}$ & $0.28 \pm 0.01$ & $37.71 \pm 0.60^{*}$ & $0.050 \pm 0.001$ & $442 \pm 48^{*}$ \\
& Male & $1.87 \pm 0.06^{*}$ & $0.33 \pm 0.01$ & $38.67 \pm 0.44^{*}$ & $0.048 \pm 0.001$ & $455 \pm 33^{*}$ \\
\hline
\end{tabular}

a Livers, kidneys, and blood were collected from C57BKS and db/db mice at 9 weeks of age. $\left(^{*}\right)$ indicates values significantly different from control ( $\mathrm{p} \leq 0.05$ ). All weights expressed in grams \pm SEM. Asterisk $\left(^{*}\right)$ represents statistically significant difference of parameters between C57BKS and $\mathrm{db} / \mathrm{db}$ mice $(p \leq 0.05)$. 
C57BKS mice than in female C57BKS mice (Figure 1A), which is consistent with $\mathrm{C} 57 \mathrm{Bl} / 6$ mice [23]. Slco1a1 mRNA expression was markedly downregulated in livers of male and female db/db mice. Slc10a1 (Ntcp) mRNA expression was increased in $\mathrm{db} / \mathrm{db}$ females as compared to C57BKS females.

Figure 1B illustrates the relative protein expression of Slco1a1 and 1b2 in crude membrane fractions isolated from livers of $\mathrm{C} 57 \mathrm{BKS}$ and $\mathrm{db} / \mathrm{db}$ mice. Figure $1 \mathrm{C}$ shows the quantification of western blots in Figure 1B. Slco1a1 protein levels were markedly downregulated in livers of $\mathrm{db} / \mathrm{db}$ mice. Slco1b2 protein expression in liver was also markedly downregulated by about $50 \%$ in $\mathrm{db} / \mathrm{db}$ males and females as compared to C57BKS mice.

\section{$\mathrm{Db} / \mathrm{db}$ mice exhibit altered efflux transporter mRNA and protein expression in liver}

Multidrug resistance-associated proteins are efflux transporters that facilitate efflux of chemicals out of hepatocytes into bile or blood. Figure 2 illustrates mRNA and protein expression of Abc transporters localized to the canalicular membrane in livers of $\mathrm{db} / \mathrm{db}$ and C57BKS mice. Abcg2 mRNA expression was higher in C57BKS males than C57BKS females. Abcc 2 mRNA levels in livers of $\mathrm{db} / \mathrm{db}$ males and females were 2 and 1.5 fold higher than C57BKS males, respectively. Abcc2 protein expression was also upregulated in $\mathrm{db} / \mathrm{db}$ males as compared to C57BKS mice. Abcg2 mRNA and protein expression also increased with the diabetes phenotype, wherein mRNA expression doubled in $\mathrm{db} / \mathrm{db}$ males and females. Correspondingly, Abcg 2 protein levels were increased by $50 \%$ and $100 \%$ in livers of $\mathrm{db} / \mathrm{db}$ male and female mice, respectively. Abcb11 and Abcb1 mRNA expression was decreased in $\mathrm{db} / \mathrm{db}$ females as compared to C57BKS females.

Figure 3A illustrates mRNA expression for efflux transporters localized to the sinusoidal and/or basolateral membrane. $\mathrm{Db} / \mathrm{db}$ males have higher expression of Abcc 5 than $d b / d b$ females. In general, $d b / d b$ mice display increased Abcc transporter expression as compared to $\mathrm{C} 57 \mathrm{BKS}$ mice. $\mathrm{Db} / \mathrm{db}$ male mice expressed Abcc3 and

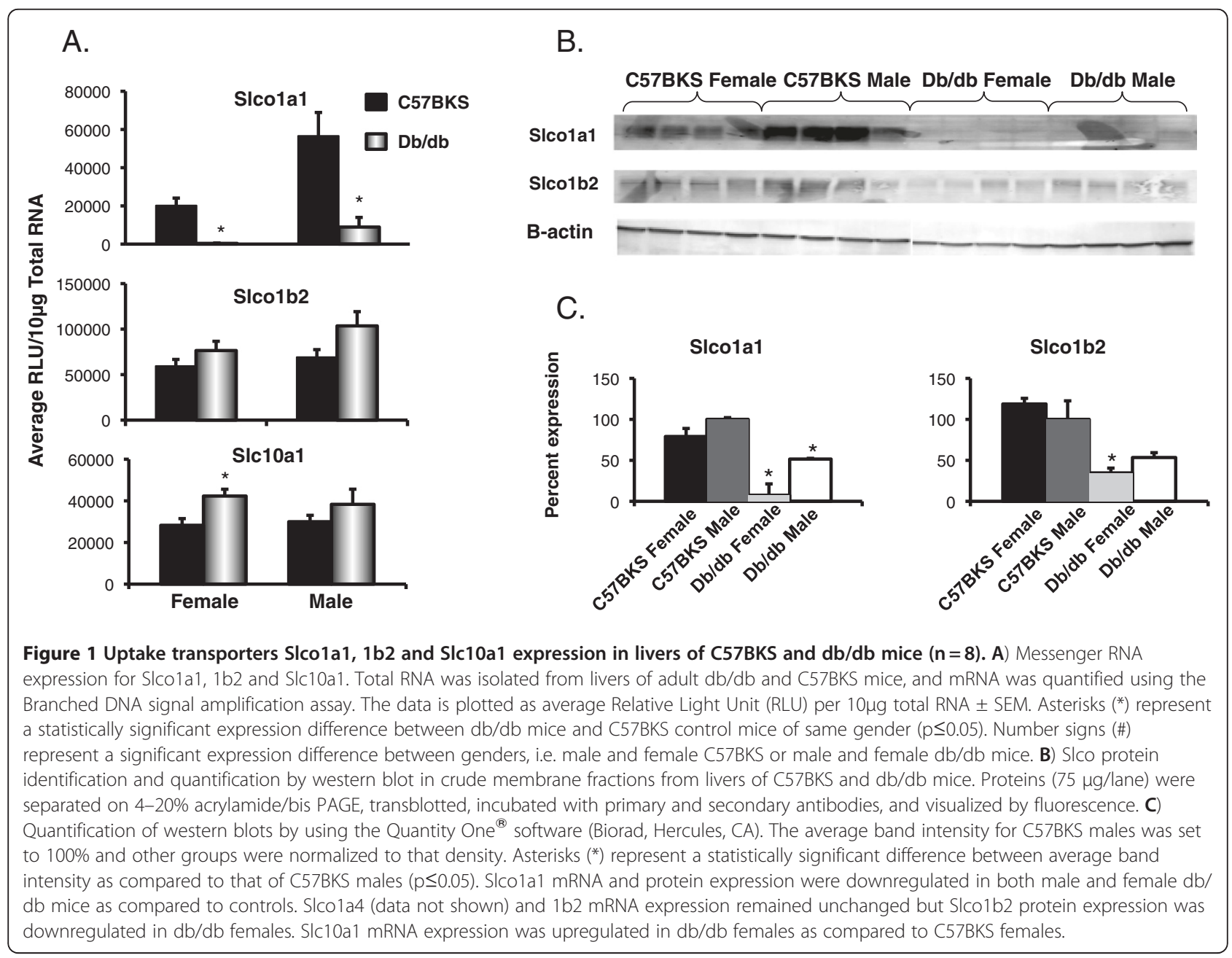




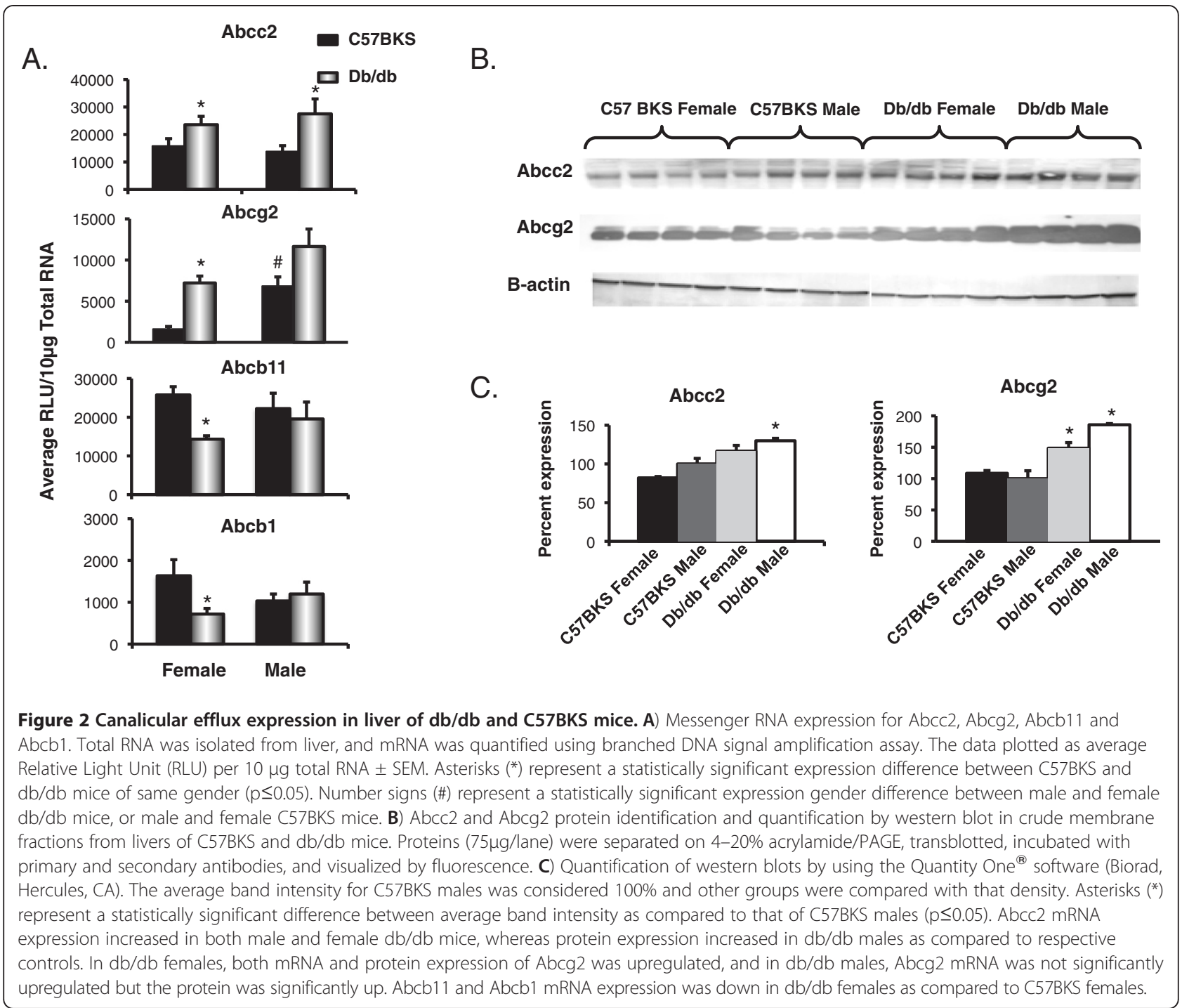

4 mRNA levels in liver that were 2.7 and 2.4 fold higher, respectively, than $\mathrm{C} 57 \mathrm{BKS}$ males. $\mathrm{Db} / \mathrm{db}$ female mice expressed Abcc 3 and 4 mRNA almost 1.8 fold more than C57BKS females. Abcc5 mRNA expression in liver was unchanged in females, but was increased 1.3-fold in livers of $\mathrm{db} / \mathrm{db}$ males. Abcc6 mRNA expression was unaltered in livers of $\mathrm{db} / \mathrm{db}$ females, but was 2.1 fold higher in $\mathrm{db} / \mathrm{db}$ males than that in C57BKS males.

Figures $3 \mathrm{~B}$ and $\mathrm{C}$ illustrate Abcc protein expression in crude membrane fractions isolated from livers of male and female $\mathrm{db} / \mathrm{db}$ and C57BKS mice. Abcc1, 2, 4 protein expression in liver did not differ between males and females. Abcc6 protein expression in liver was higher in females than males. Abcc1 protein expression was significantly upregulated by 5 - and 2.6-fold in male and female $\mathrm{db} / \mathrm{db}$ mice, respectively. Liver Abcc3 and 4 protein expression was 3-4 fold higher in $\mathrm{db} / \mathrm{db}$ mice compared to $\mathrm{C} 57 \mathrm{BKS}$ mice. Increased sinusoidal/basolateral Abcc3 staining was also observed in livers of male $\mathrm{db} / \mathrm{db}$ mice (Figure 4). The staining observed was consistent with that previously reported [24]. Db/db females also expressed increased Abcc6 protein levels in liver did not differ between $\mathrm{db} / \mathrm{db}$ and C57BKS mice.

\section{$\mathrm{Db} / \mathrm{db}$ mice exhibit altered transporter mRNA and protein expression in kidney}

Slco1a1, 1a6, Slc22a1, Slc22a2, Slc22a6, Slc22a7, Abcc1-4, Abcb1, Abcg2 mRNA expression was quantified in kidneys of $\mathrm{db} / \mathrm{db}$ and C57BKS mice (Figures 5 and 6). Basal expression of Slcola1 mRNA in males was more than females, in both phenotypes. Also, Slc22a2 and $22 \mathrm{a} 6$ mRNA was expressed more in C57BKS males than C57BKS females. Slco1a1 mRNA expression was significantly lower in kidneys of $\mathrm{db} / \mathrm{db}$ than that expressed in 


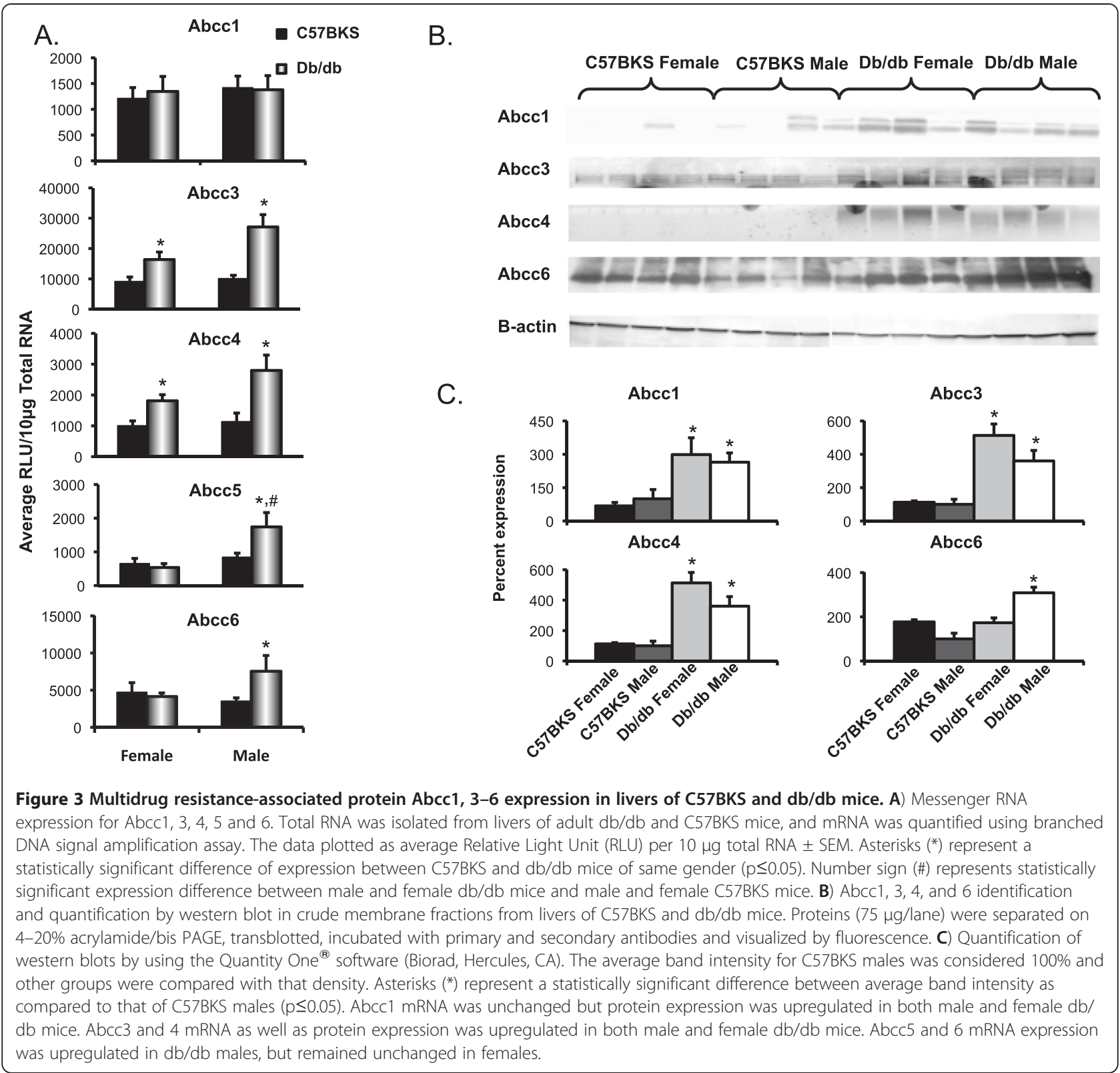

C57BKS mice, with expression approaching undetectable levels. Slcola1 protein expression was also decreased in $\mathrm{db} / \mathrm{db}$ females as compared to C57BKS females. In female $\mathrm{db} / \mathrm{db}$ mice, Slcola6 mRNA expression was decreased to only about $40 \%$ of that detected in kidneys of C57BKS females. Slc22a7 expression was markedly lower in kidneys of male and female $\mathrm{db} / \mathrm{db}$ mice as compared to C57BKS controls. Slc22a6 mRNA expression was unchanged in kidneys of $\mathrm{db} / \mathrm{db}$ females, but in $\mathrm{db} / \mathrm{db}$ males was significantly reduced to about one third of that expressed in kidneys of male C57BKS mice. Slc22a2 mRNA expression was decreased to about $25 \%$ of controls in kidneys of male $\mathrm{db} / \mathrm{db}$ mice, but was similarly expressed in kidneys of $\mathrm{db} / \mathrm{db}$ and C57BKS females. Slc22a1 mRNA expression in kidneys was similar between genotypes.

Among efflux transporters, expression of Abccs was altered in kidneys of $\mathrm{db} / \mathrm{db}$ mice. $\mathrm{Db} / \mathrm{db}$ females exhibited marked down regulation of Abcc3 mRNA in kidney compared to C57BKS female mice. Basal Abcc3 mRNA expression was markedly higher in female kidneys as compared to male kidneys, which is consistent with other published studies [14]. Abcc4 mRNA expression was unchanged in $\mathrm{db} / \mathrm{db}$ females, but was significantly increased, by almost 3 -fold in kidneys of $\mathrm{db} / \mathrm{db}$ male mice, as compared to that detected in male C57BKS mice. Also, basal expression of Abcc4 mRNA as well as 


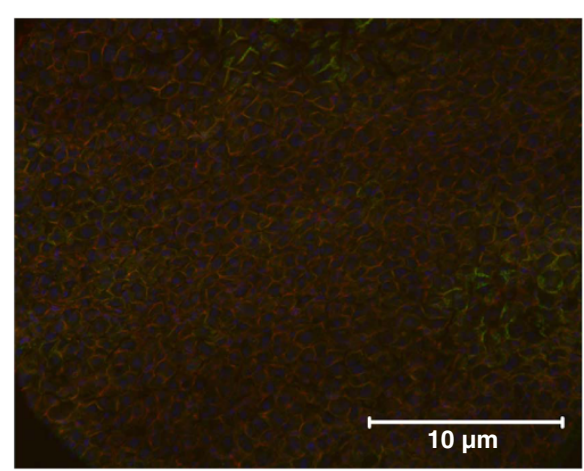

C57BKS Female

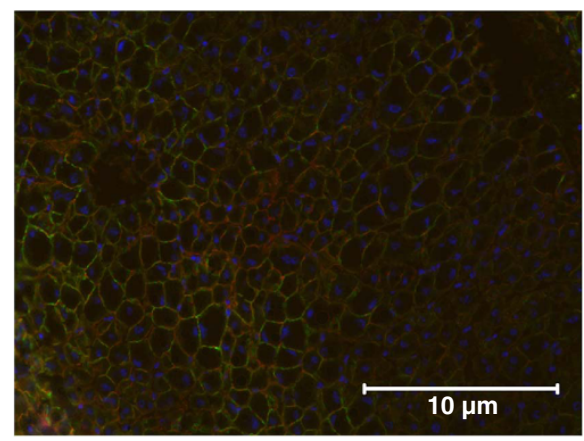

$\mathrm{Db} / \mathrm{db}$ Female

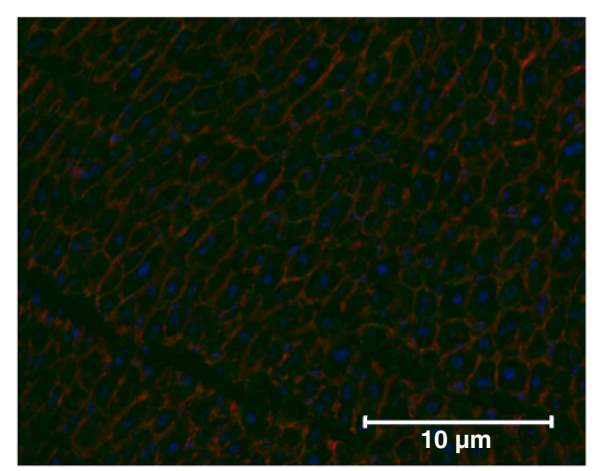

C57BKS Male

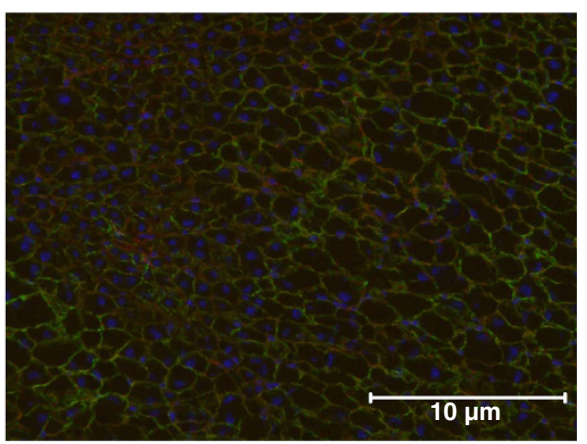

$\mathrm{Db} / \mathrm{db}$ Male

Figure 4 Immunohistochemical staining of liver sections for Abcc3 detection. Frozen livers were cut to $5 \mu \mathrm{m}$ cryosections and fixed in $4 \%$ paraformaldehyde in phosphate-buffered saline (PBS). Sections were blocked in goat serum followed by incubation with anti-Abcc3. Sections were washed with PBS and incubated with goat anti-rat lgG conjugated to Alexfluor 488 (green staining) and rhodamine-conjugated phalloidin (red). Sections were then rinsed with PBS/T, PBS, and water, air dried, and then mounted with Prolong Gold containing DAPI (blue staining). All images are displayed as 200X magnification. It was observed that green staining displaying Abcc3 expression was higher in db/db male and female mice as compared to controls.

protein in female kidney was almost 3-fold higher than that expressed male kidney. Abcc2 mRNA expression in kidney did not differ between $\mathrm{db} / \mathrm{db}$ and C57BKS mice for either gender (data not shown).

\section{$\mathrm{Db} / \mathrm{db}$ mice exhibit altered nuclear receptor and receptor target gene expression}

The relative expression of the transcription factor, nuclear factor E2 related factor 2 (Nrf2), as well as nuclear hormone receptors peroxisome proliferator activated receptor alpha (Ppar- $\alpha)$, constitutive androstane receptor (Car), farnesoid-X-receptor (Fxr) and pregnane-X-receptor (Pxr) mRNA expression was quantified in livers of $\mathrm{db} / \mathrm{db}$ mice (Figure 7). In both male and female $\mathrm{db} / \mathrm{db}$ mice, $\mathrm{Nrf} 2$ mRNA expression was significantly increased compared to C57BKS controls. Glutamate cysteine ligase (Gclc), a Nrf2 target gene, was correspondingly increased in livers of $\mathrm{db} /$ $\mathrm{db}$ mice. Ppar- $\alpha$, and its target gene Cyp4a14 mRNA expression were also higher in male and female $\mathrm{db} / \mathrm{db}$ mice as compared to C57BKS mice. Similarly, Car and Cyp2b10 expression also increased in male $\mathrm{db} / \mathrm{db}$ mice as compared to $\mathrm{C} 57 \mathrm{BKS}$. Female $\mathrm{db} / \mathrm{db}$ mice also displayed increased Cyp2b10, however, Car was unchanged. Pxr mRNA expression was not altered, however, its target Cyp3a11 expression was increased in $\mathrm{db} / \mathrm{db}$ males. Similarly, Fxr mRNA did not increase significantly, however, one of its target genes, small heterodimer partner (Shp) was increased in $\mathrm{db} / \mathrm{db}$ females compared to C57BKS females.

\section{$\mathrm{Db} / \mathrm{db}$ mice exhibit increased urine APAP and APAP} metabolites levels, and enhanced expression of UDP glucuronosyl transferase (Ugt) $1 \mathrm{a} 6$ and sulfotransferase (Sult) 1a1

Prior work in male rats demonstrated that APAP-G is a substrate for mouse and rat Abcc3 [25], and induction of Abcc3 expression in liver is associated with increased vectorial excretion of APAP-G [26,27]. Additionally, in mice, Abcc3 and 4 contribute to the basolateral excretion of APAP-sulfate (APAP-S) [25]. Because of Abcc3 and 4 transporters expression was significantly elevated in livers of $\mathrm{db}$ / $\mathrm{db}$ mice, and Abcc4 expression was significantly elevated in kidney, an additional study aimed to explore whether APAP-G and -S excretion into urine was increased. Therefore, a low, non-toxic APAP dose (100 mg/kg, po) was administered to male $\mathrm{C} 57 \mathrm{BKS}$ and $\mathrm{db} / \mathrm{db}$ mice, and of the total amount of urine APAP-G and APAP-S was quantified 


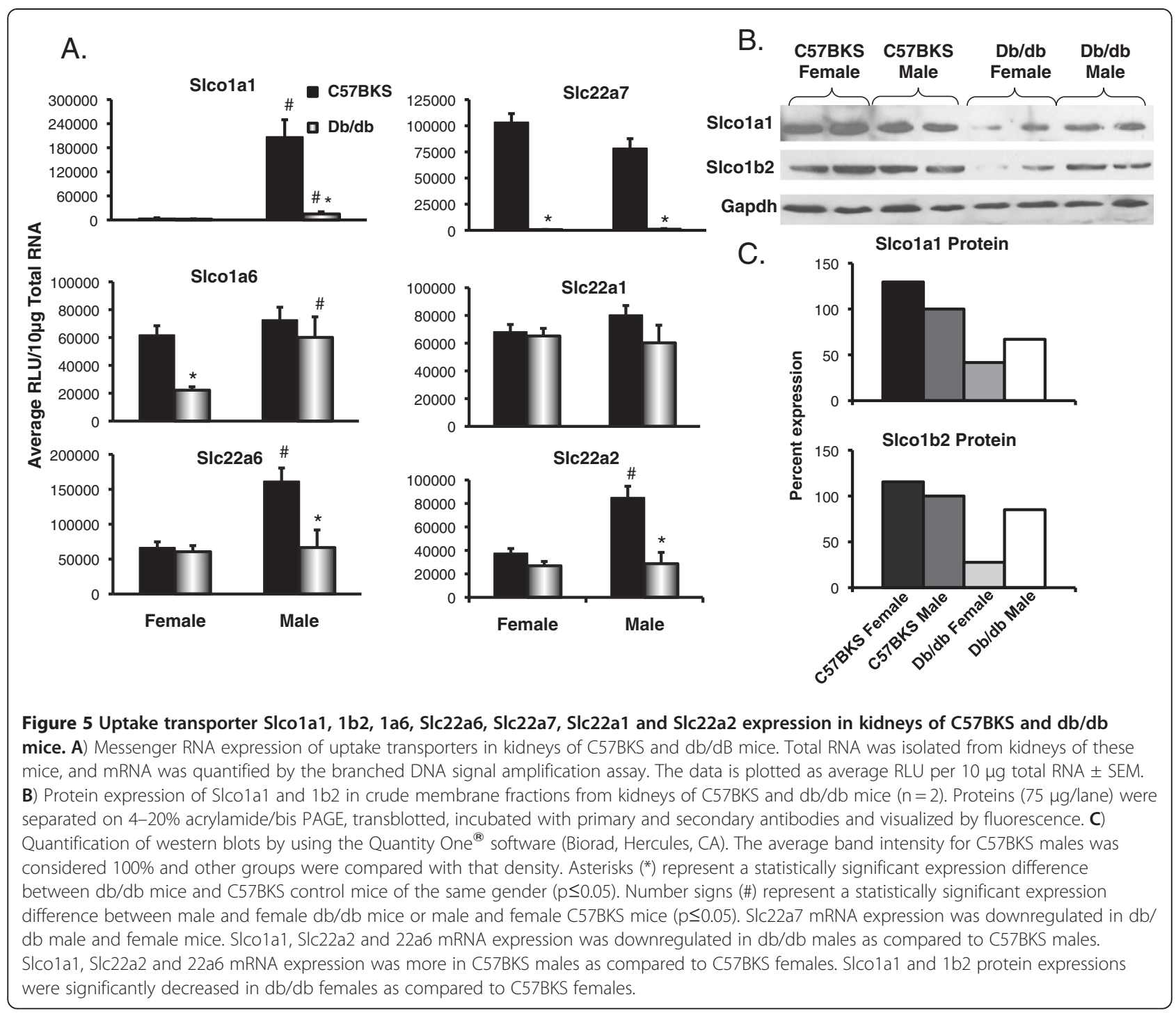

24 hours after administration (Figure 8A). Urine flow rates were average $1 \mathrm{~mL} / 24 \mathrm{hr}$ for C57BKS and $2.7 \mathrm{~mL} / 24 \mathrm{hr}$ for $\mathrm{db} / \mathrm{db}$ male mice. Taking differences in body weight into account, urine APAP-G and APAP-S amounts in urine were twice as high as that in urines from C57BKS mice. Thus, cumulative excretion of APAP conjugation metabolites was higher in $\mathrm{db} / \mathrm{db}$ mice. As Ugt1a6 and Sult1a1 are primary conjugation enzymes for APAP-G and APAP-S production $[28,29]$, their mRNA expression was evaluated (Figure 8B). Ugt1a6 and Sult1a1 mRNA expression was increased in male $\mathrm{db} / \mathrm{db}$ mice as compared to C57BKS mice, which corresponded with increased APAP-G and APAP-S levels in urine.

\section{Discussion}

The current study demonstrates that $\mathrm{db} / \mathrm{db}$ mice, which are a widely used rodent model of diabetes with excessive weight gain and NAFLD, display profound alteration of transporter expression in both liver and kidney at the level of mRNA and protein expression. These observations are in agreement with [14] and [30]. Increased urine APAP-G and $-\mathrm{S}$ levels were also observed, which consistent with enhanced APAP-G disposition observed in other rodent steatosis models [19]. Slcola1 expression was markedly downregulated in livers and kidneys of $\mathrm{db} /$ $\mathrm{db}$ mice. As Slcolal mediates transport of wide variety of anionic, cationic, zwitterionic, as well as, neutral chemicals [31], a significant decrease in Slcola1 expression in liver and kidney could cause marked changes in pharmacokinetics and toxicity in the $\mathrm{db} / \mathrm{db}$ mouse model. Along with Slco1a1, Slco1b2 protein expression was significantly decreased in livers of $\mathrm{db} / \mathrm{db}$ female mice. In mice, Slcola1, transports similar substrates as SLCO1A2, $1 \mathrm{~B} 1$ and 1B3 in humans [32]. As Ppar- $\alpha$ has a central role in the down regulation of Slcola1 in mouse liver $[33,34]$, and is upregulated in $\mathrm{db} / \mathrm{db}$ liver, according 


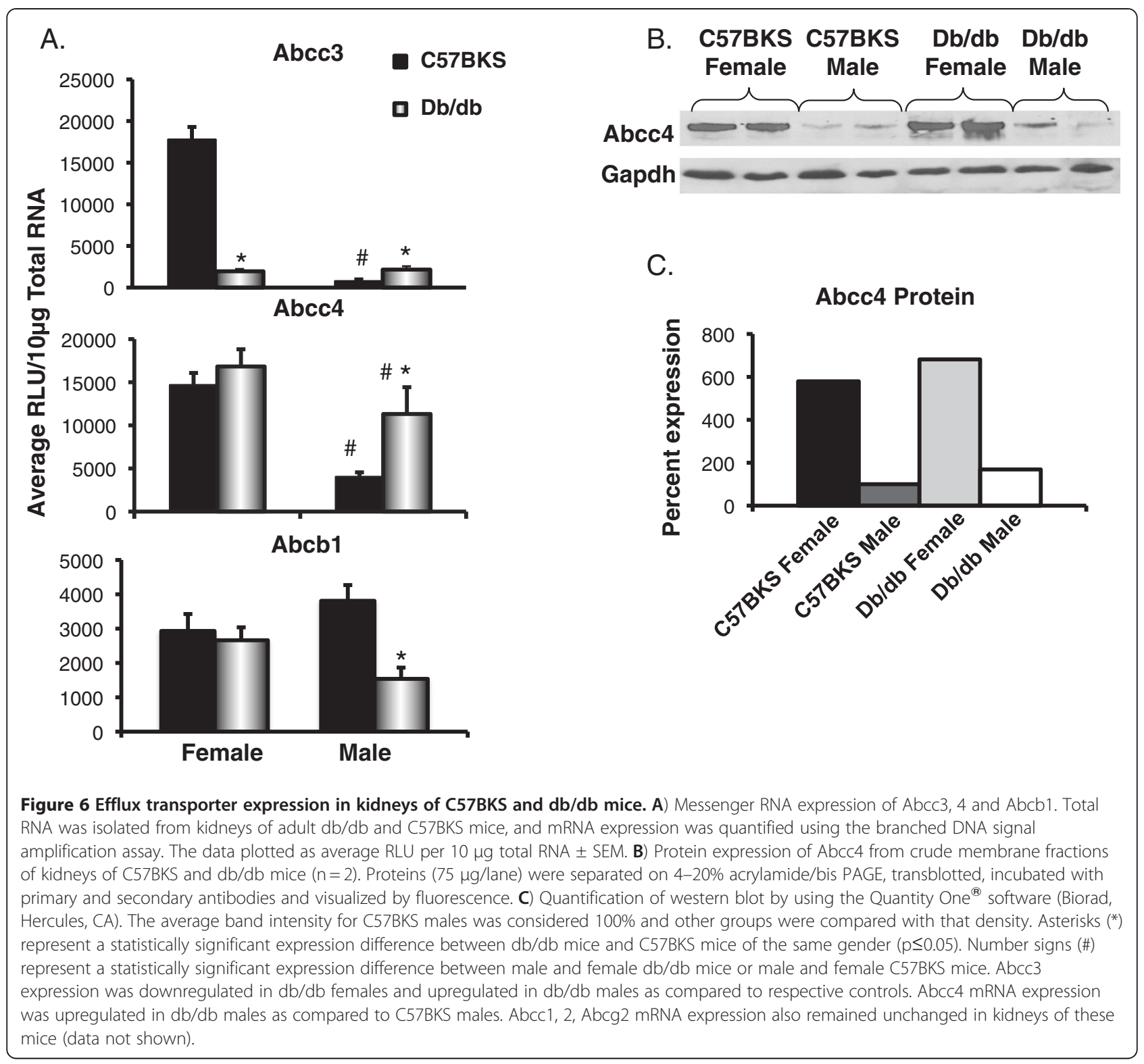

to present study as well as previous findings [35], it is possible that the observed downregulation is via a Ppar- $\alpha$ mediated mechanism. Also, as Fxr has been observed to be decreased in NALFD [36], it is possible Fxr-dependent mechanisms regulate Slco expression. Fxr regulates mouse Slco1a1, 1a4 and 1a5 [37]. Pxr also regulates Slcola4 expression in mice [38]. Similarly, human SLCO1B3 and 1A2 is regulated, in part, by FXR [39]. However, $\mathrm{db} / \mathrm{db}$ mice did not demonstrate any significant differences in mRNA expression of Fxr and Pxr in liver, suggesting that in the observed Slco decrease in $\mathrm{Db} / \mathrm{Db}$ mice may be due to Ppar- $\alpha$ activation, and not Pxr and Fxr alterations. These observed changes in Slco expression in $\mathrm{db} / \mathrm{db}$ mice could be predicative of SLCO expression changes in livers of diabetic humans. Further studies, which reveal nuclear receptor binding to specific response elements present in Slco promoters, will further elucidate how these transporters are regulated in leptin/ leptin receptor deficient diabetes models.

The regulation of renal transporter expression in mouse models of diabetes and obesity remains limited. Data in this manuscript and Cheng et al. [14] indicate that a severe diabetes phenotype alters renal transporter expression. It is intriguing that kidney transporter expression was substantially altered in this model, but minimal changes in renal pathology were observed. In humans SLC22A6 and SLC22A7 are predominant transporters localized to the basolateral membrane of renal proximal tubule cells [40]. The SLCs transport certain antibiotics like benzylpenicillin, antivirals and NSAIDs 


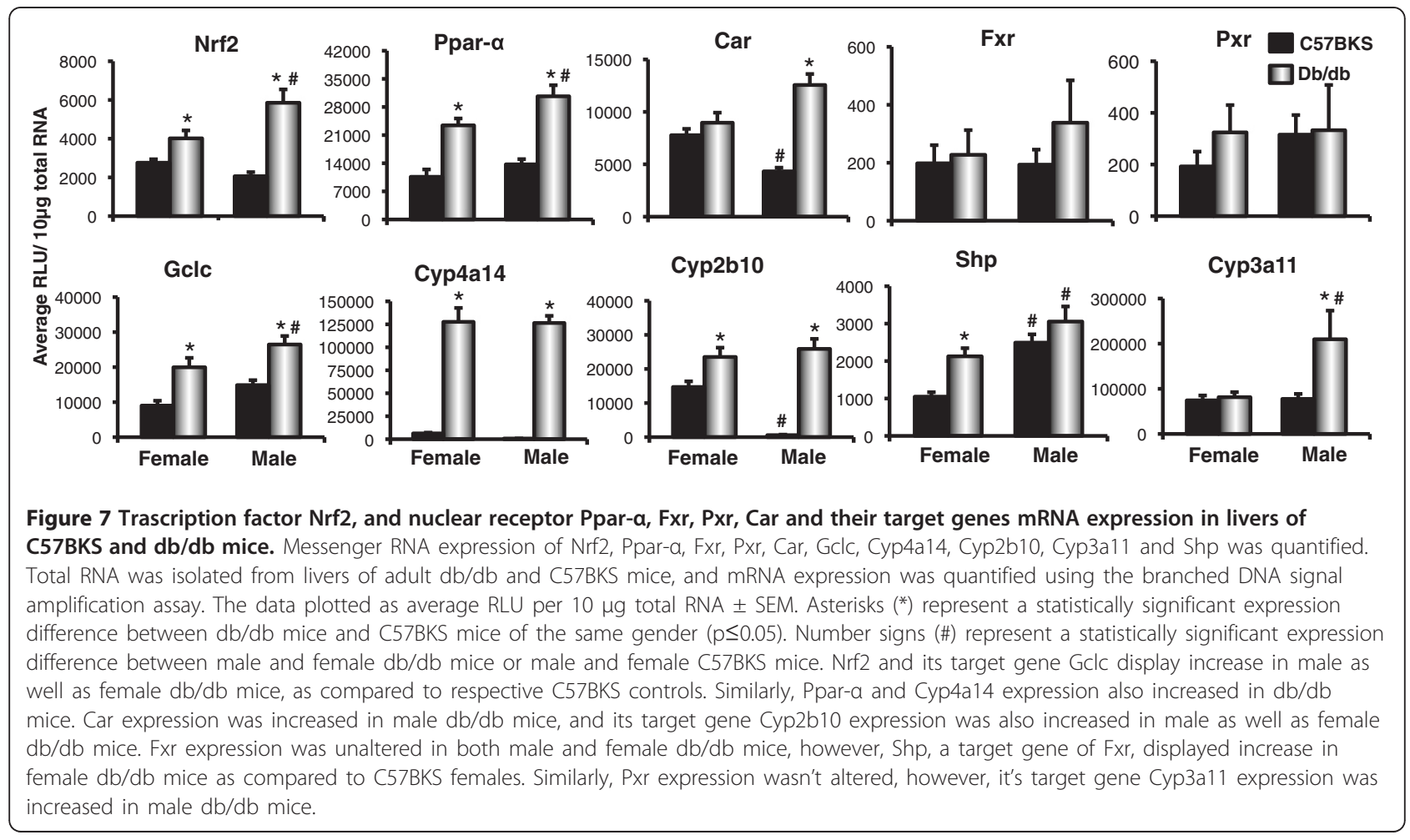

(Non-steroidal anti-inflammatory drugs). Slc22a7 expression was virtually undetectable in $\mathrm{db} / \mathrm{db}$ male and female mice as compared to respective C57BKS controls, indicating the possibility of different renal elimination of substrates such as antibiotics, antivirals and non-steroidal anti-inflammatory drugs in this model. Slc22a6 and Slc22a2 expression was also downregulated in $\mathrm{db} / \mathrm{db}$ mice, especially males. The mechanism for the observed Slc downregulation was not determined, however HNF1 has been described to regulate human and mouse SLC22A7/Slc22a7 and HNF4 has been described to regulate SLC22A7 in kidney [41,42].

Efflux transporters, in general, were upregulated in livers of $\mathrm{db} / \mathrm{db}$ mice. Abcc3 transports mono-ionic bile acids such as glycocholate and taurocholate [43], as well as glucuronide or glutathione conjugates of certain drugs (e.g. APAP-G and morphine-3-glucuronide) [44]. Abcc3 and 4 expressions were significantly upregulated in $\mathrm{db} / \mathrm{db}$ mice livers, in both genders. Abcc4 also transports bile acids, antiviral drugs, and cyclic nucleotides [15], but also contributes to the basolateral excretion of APAP-S $[45,46]$. Reisman et al. demonstrated increased plasma APAP-G and APAP-S concentrations correspond with increased Abcc 3 and 4 protein expression, respectively [47]. Additionally, in a rat model of NASH, it was observed that increased Abcc3 expression enhanced urinary excretion of APAP-G [19]. Increased expression of Abcc3 and/or Abcc4 is associated with enhanced excretion of APAP metabolites $[19,48]$. In the present study, db/db mice had higher amounts of APAP-G and -S metabolites in urine, which was consistent with increased hepatic Abcc3 expression, and increased hepatic and renal Abcc4 expression. The reasons for higher excretion of APAP-G and APAP should be due to enhanced production of APAP-G and $-\mathrm{S}$ and/or enhanced basolateral excretion. $\mathrm{Db} / \mathrm{db}$ mice also display increase in mRNA expression of the enzymes responsible for production of major conjugation metabolites like Ugt1a6 and Sult1a1 compared to C57BKS mice livers (Figure 8). Therefore, enhanced excretion of glucuronide and sulfate metabolites was expected. Overall, this data is consistent with published findings in children with NAFLD [22]. Increased APAP-G levels were observed in plasma and urine samples from children presenting with NAFLD [22]. Abcc1, 2, 4, and Abcg2 mRNA and/or protein expression was increased in liver, which is consistent with what was observed in livers of T2DM rats [49]. Abcc1 and Abcg2, along with Abcb1, can transport the antidiabetic drug rosiglitazone [50]. Severe liver injury has been reported in a person with T2DM [51] and cholestatic injury has also been observed after rosiglitazone therapy [52] - both suggesting hepatic clearance is necessary. Perhaps, differences in expression of these transporters in the diabetic liver could contribute to decreased hepatic clearance of rosiglitazone. An interesting observation is that rosiglitazone increases the incidence of cardiovascular disease in diabetic patients [53]. As its use is still approved, determining whether diabetes 


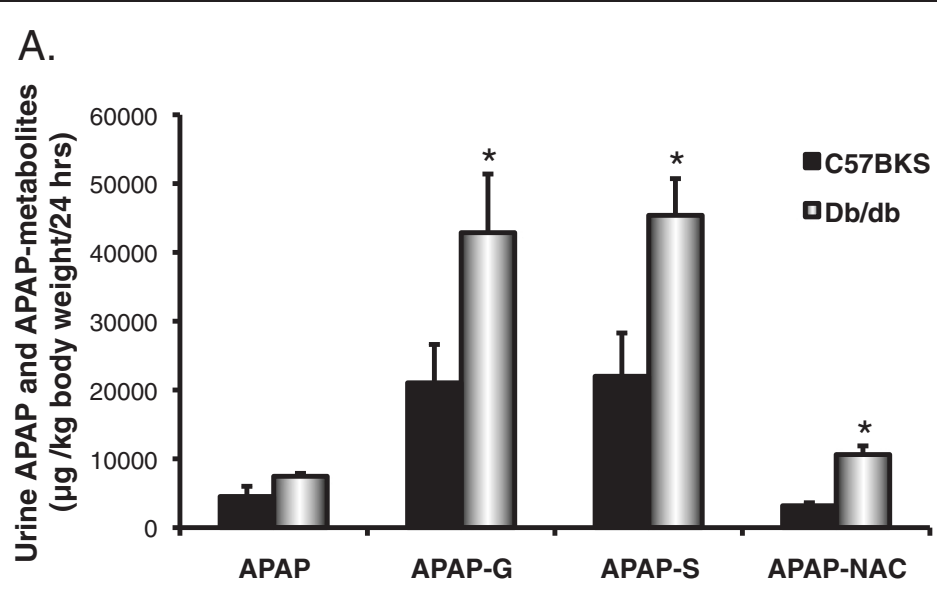

B.

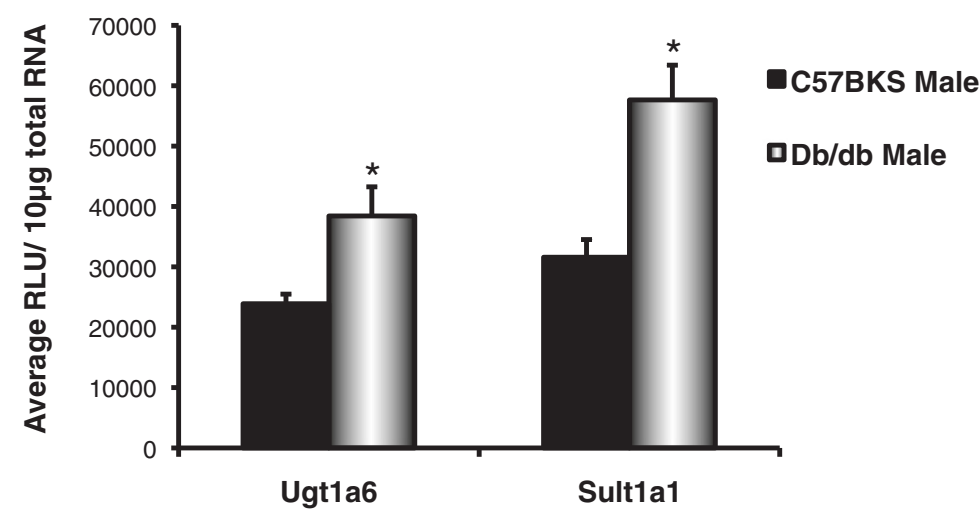

Figure 8 Urine acetaminophen (APAP) and acetaminophen metabolite concentrations and APAP metabolizing enzymes expression in male C57BKS and db/db mice. A) Urinary levels of APAP and its conjugation metabolites glucuronide, sulfate, and $\mathrm{N}$-acetyl cysteine levels in male C57BKS and db/db mice. Acetaminophen (150 mg/kg, po) was administered to C57BKS and db/db male mice $(n=5)$, mice were housed in metabolic cages and urine was collected for $24 \mathrm{hrs}$. Urine proteins were precipitated by methanol precipitation and the extracted samples analyzed by HPLC. Asterisks $\left(^{*}\right)$ represent a statistically significant concentration difference between C57BKS and db/db mice ( $\left.p \leq 0.05\right)$. APAPglucuronide (APAP-G), sulfate (APAP-S), and N-acetyl L-cysteine were detected in higher amounts in urine of db/dB mice as compared to C57BKS. B) Messenger RNA expression of Ugt1a6 and Sult1a1 in livers of male C57BKS and db/db mice. Total RNA was isolated from livers of adult db/db and C57BKS male mice, and mRNA expression was quantified using the branched DNA signal amplification assay. The data plotted as average RLU per $10 \mu \mathrm{g}$ total RNA \pm SEM. Asterisks $\left(^{*}\right)$ represent a statistically significant expression difference between $\mathrm{db} / \mathrm{db}$ mice and C57BKS mice of the same gender $(p \leq 0.05)$. Both Ugt1a6 and Sult1a1 mRNA expression was increased significantly in livers of male db/db mice as compared to C57BKS mice.

could impede rosiglitazone clearance is important for predicting persons at risk.

The transporters analyzed in this study are known to be regulated by different mechanisms, involving various transcription factors such as Ppar- $\alpha$, Pxr, constitutive androstane receptor (Car), nuclear factor E2-related factor 2 (Nrf2), Fxr, and Hepatocyte nuclear factor 1-alpha $(\mathrm{Hnf}-1 \alpha)$. Li and Klaassen (2004) showed that HNF1 $\alpha$ levels are critical for constitutive expression of Slco1b2 in mouse liver [54]. Also Slc22a6 and Slc22a7 expression in mouse kidneys is downregulated by targeted disruption HNF1 $\alpha$ [55]. Significantly reduced expression of Slco1a1 in liver, along with Slc22a7 in kidney in $\mathrm{db} / \mathrm{db}$ mice suggests that HNF1 $\alpha$ levels or binding is decreased in these mice. Similarly, Abcc3 and Abcc4 efflux transporter expression is regulated in part by Nrf2-keap1 pathway in liver [24]. The present study clearly demonstrates that Abcc2-4 were upregulated in livers of $d b / d b$ mice, which suggests activation of the Nrf2 and/or constitutive androstane pathways in these mice. Increased mRNA expression of Nrf2 and its target gene Gclc indicate that Nrf2-keap1 pathway is likely activated in $\mathrm{db} / \mathrm{db}$ mice. The Nrf2-keap1 pathway is activated during periods of oxidative stress [56]. Also as reviewed by Rolo and Palmeira, diabetes is typically accompanied by increased production of free radicals, present findings 
suggests that oxidative stress may be present in diabetic liver [57]. Together, the data presented argue for additional future studies to better define nuclear receptor pathways that are upregulated in leptin/leptin receptor deficient models, which will aid in better understanding receptor-mediated mechanisms, which could regulate transporter expression in steatosis and T2DM. As reviewed by Klaassen and Slitt [38], Car and Pxr are also known for regulating Abcc2, 3, 5, 6 and Abcc2, 3 respectively. The observed increase in Abcc2, 3, 5, and 6 expression could be attributed to the observed increased in Car expression and activity, as shown in Figure 7.

Similar to the liver, transporter expression is markedly altered in kidneys of $\mathrm{db} / \mathrm{db}$ mice. Maher and colleagues showed that targeted disruption in Hnf1 $\alpha$ significantly downregulated Slc22a6, 7 and 8 and Slcola1 mRNA in mice kidneys [55]. This indicates that $\mathrm{db} / \mathrm{db}$ mice might have differential expression or binding of Hnf1 $\alpha$. Also, these mice have severe hyperglycemia. During normal course, almost all of the glucose is absorbed from the nephrons during urine formation. But due to overwhelming amounts of glucose in glomerular filtrate, kidneys are unable to absorb it and thus excrete glucose in urine. This hyperglycemic urine may cause some alterations in transporter expression in kidneys.

\section{Conclusions}

Data illustrated in the present study illustrate a comprehensive, panoramic view of how a severe diabetes phenotype affects liver and kidney transporter expression in mice. These changes were associated with altered excretion of the APAP metabolites, APAP-G and $-\mathrm{S}$, which is consistent with a recent publication in children with NAFLD [22]. Changes in transporter expression could, in part, explain why certain drugs have altered ADME in humans with diabetes. In summary, we demonstrate that $\mathrm{db} / \mathrm{db}$ mice, which exhibit a severe diabetes phenotype display marked alterations in transporter expression in liver and kidney.

\section{Methods}

\section{Animals and husbandry}

Seven-week-old C57BKS and $\mathrm{db} / \mathrm{db}$ (BKS.Cg-m +/+ Leprdb/J, Jax mice stock \# 000642) mice $(\mathrm{n}=8$, for each strain and gender) were purchased from Jackson Laboratories (Bar Harbor, ME). Mice were housed for 2 weeks under a constant dark/light cycle $(12 \mathrm{hr} / 12 \mathrm{hr})$ and given food and water ad libitum. The mice were fed the same feed (LabDiet 5 K20) as at Jackson laboratories in order to maintain a consistent food source. During acclimation, body weight and blood glucose levels (Glucose meter, Bayer Healthcare, Tarrytown, NY) were measured each week. After 2 weeks of acclimation mice were anesthetized by isofluorane inhalation -9 weeks of age was selected to evaluate expression in $\mathrm{db} / \mathrm{db}$ mice because the mice have reached maturity, and exhibit significantly elevated blood glucose levels along with hepatic steatosis, as well as, to compare previous transporter expression observations in ob/ob mice [14]. Blood was collected and serum was obtained after centrifugation at $2300 \mathrm{xg}$ for 5 minutes at $4^{\circ} \mathrm{C}$. Livers and kidneys were collected, snap frozen in liquid nitrogen, and stored at $-80^{\circ} \mathrm{C}$ for future analysis. Experiments were approved by The University of Rhode Island Institutional Animal Care and Use Committee (IACUC).

\section{RNA extraction}

Total RNA from liver and kidney was isolated by phenolchloroform extraction using RNA Bee reagent (Tel-Test Inc, Friendswood, TX) according to the manufacturer's protocol. RNA concentration was quantified by absorbance at $260 \mathrm{~nm}$ using a spectrophotometer (Nanodrop ND1000, Thermo Fisher Scientific, Waltham, MA) and the samples were diluted to $1 \mu \mathrm{g} / \mu \mathrm{L}$. Formaldehyde-agarose gel electrophoresis followed by UV illumination was used to visualize RNA and confirm integrity.

\section{Oligonucleotide probesets for branched DNA signal amplification (bDNA) assay}

Probe sets for mouse Abcc1-6, Slc22a6, 7, 8, Slcola1, 1a4, 1b2, 1a6, 2b1, Nrf2, Gclc, Fxr, Shp, Ppar- $\alpha$, Car, Pxr, Cyp3a11, Cyp2b10 and Cyp4a14 have been described previously $[23,33,58,59]$. Oligonucleotide probesets required for the assay were graciously donated by Dr. Curtis Klaassen (University of Kansas Medical Center, Kansas City, KS).

\section{bDNA assay}

The Branched DNA assay has been employed in multiple studies to evaluate relative biotransformation enzyme and transporter mRNA expression [19,23,33]. All reagents for analysis including lysis buffer, amplifier/label probe diluent and substrate solution were supplied in the QuantiGene 1.0 assay kit (Panomics, Fremont, CA). Oligonucleotides were first dissolved in $10 \mathrm{mM}$ Tris- $\mathrm{HCl}$ (pH 8.0) with $1 \mathrm{mM}$ EDTA and were diluted 1:100 in lysis buffer before use [60]. On day one, total RNA samples $(10 \mu \mathrm{g}, 1 \mu \mathrm{g} / \mu \mathrm{L})$ were added to wells containing 50 $\mu \mathrm{L}$ of capture hybridization buffer and $50 \mu \mathrm{L}$ of diluted probe set. The RNA was allowed to hybridize overnight with probe set at $53^{\circ} \mathrm{C}$. On day two, subsequent hybridization steps were followed as mentioned in manufacturer's protocol, and fluorescence was measured with a GloRunner ${ }^{\mathrm{TM}}$ microplate luminometer interfaced with GloRunner DXL Software (Turner Biosystems, Sunnywale, CA). The fluorescence for each well was reported as relative light units (RLU) per $10 \mu \mathrm{g}$ of total RNA. 


\section{Preparation of crude membrane preparations from liver and kidneys}

Crude membrane fractions were prepared from livers and kidney, as this fraction has been previously described for measurement of transporter expression [24,61]. Approximately $50 \mathrm{mg}$ of tissue was homogenized in Sucrose-Tris (ST) buffer (250 mM sucrose $10 \mathrm{mM}$ Tris- $\mathrm{HCl}$ buffer, $\mathrm{pH}$ 7.4) and containing protease inhibitor cocktail $(2 \mu \mathrm{g} / \mathrm{mL}$, Sigma-Aldrich, Co, St. Louis, MO). Homogenates were centrifuged at 100,000 g for $60 \mathrm{~min}$ at $4^{\circ} \mathrm{C}$. ST buffer $(200 \mu \mathrm{l})$ was used to resuspend the resulting pellet. Protein concentration of the crude membrane fractions was determined using the Biorad DC protein assay reagent (Bio-Rad Laboratories, Hercules, CA).

\section{Western blot analysis of crude membrane fractions}

Western blot analysis was used for identification and quantification of specific transport proteins. Crude membrane fractions (50 $\mu \mathrm{g}$ protein/well) were electrophoretically resolved by SDS-Polyacrylamide gel (4-20\%) electrophoresis. Proteins were transblotted onto polyvinylidene fluoride (PVDF) membrane (Millipore, Bedford, $\mathrm{MA})$ at $100 \mathrm{~V}$ for 45 minutes. The membrane was blocked overnight at $4^{\circ} \mathrm{C}$ with $2 \%$ non-fat dry milk in phosphate-buffered saline with $0.05 \%$ Tween 20 (PBS/T). The membrane was then incubated with primary antibody in PBS/T for 3 hrs at room temperature. Following three washes in PBS/T, the membrane was incubated with species-specific peroxidase-labeled secondary antibody diluted in PBS/T for 1 hour at room temperature. The specific information about the source, dilution, type, and molecular weight of primary and secondary antibodies is detailed in supplemental information (Additional file 2: Table S1). After incubation with secondary antibody, membranes were washed three times in $\mathrm{PBS} / \mathrm{T}$, incubated with ECL + fluorescence Reagent (GE Healthcare, Buckinghamshire, UK), and developed using autoradiography. Protein bands on autoradiographs were quantified using Quantity One ${ }^{\circledR}$ software v4.6.3 (Biorad, Hercules, CA). B-actin or Gapdh were used as loading controls for western blotting.

\section{Immunohistochemical staining}

Abcc3 expression and localization were evaluated because increased Abcc3 protein expression in liver is associated with changes in vectorial excretion of acetaminophenglucuronide [25]. Frozen tissues were cut into $5 \mu \mathrm{m} \mathrm{sec-}$ tions on a Vibratome cryostat and were fixed in 4\% paraformaldehyde in phosphate-buffered saline (PBS) for 5 minutes. Sections were washed twice with PBS, for 5 minutes at room temperature, and then washed once with PBS containing $0.2 \%$ Triton X-100 (PBS-Triton) for 5 minutes. Next, sections were incubated with blocking agent (5\% goat serum diluted in PBS-Triton) for 1 hour at room temperature. Blocking agent was removed and sections were then incubated with Abcc3 primary antibody (diluted 1:100 in blocking agent) for 2 hours at room temperature. Sections were washed thrice with PBS-Triton and then incubated with Alexafluor 488 goat anti-rat IgG antibodies diluted 1:100 in PBS-Triton and Rhodamine-conjugated phalloidin (Invitrogen Inc., Carlsbad, CA; diluted 1:200) for 1 hour at room temperature in dark. After incubation, sections were washed twice with PBS-Triton, followed by a wash with PBS, and then double-deionized water. Sections were allowed to air dry and were mounted with Prolong ${ }^{\circledR}$ Gold containing DAPI (Invitrogen Inc., Carlsbad, CA).

\section{Acetaminophen (APAP) disposition in C57BKS and db/db male mice}

Ten week old C57BKS and $\mathrm{db} / \mathrm{db}$ male mice $(\mathrm{n}=5)$ were obtained from Jackson Laboratories (Bar Harbor, ME). Only male mice were used for this study, as both genders exhibited increased liver Abcc3 and 4 expressions, and APAP disposition studies in rodents are typically performed using males. After two weeks acclimation, mice were administered APAP (100 mg/kg, po) in $0.9 \%$ saline. Immediately after dosing, mice were housed individually in metabolic cages equipped with urine collection trays that kept cool with custom ice packs (Techniplast, USA). The total urine volume over $24 \mathrm{hrs}$ was measured. To precipitate proteins in urine, samples $(100 \mu \mathrm{l})$ were diluted with $200 \mu \mathrm{l}$ cold methanol and centrifugated at $4,000 \mathrm{~g}$ for $30 \mathrm{~min}$ at $4^{\circ} \mathrm{C}$. The resulting supernatants were collected $(250 \mu \mathrm{l})$ and diluted with $500 \mu \mathrm{l}$ mobile phase. After mixed, the samples were centrifuged at $4,000 \mathrm{~g}$ for $10 \mathrm{~min}$ at $4^{\circ} \mathrm{C}$. $100 \mu \mathrm{l}$ of the supernatant is used for HPLC analysis. The column used for HPLC analysis was Eclipse XDB-C18 $(4.6 \mathrm{~mm} \mathrm{x} 15 \mathrm{~cm}$, $3.5 \mu \mathrm{m})$. The mobile phase A contained $8 \%$ methanol and $1 \%$ acetic acid in water, and B contained $50 \%$ methanol in water. For first 5 min, mobile phase B was maintained at $100 \%$ followed by linear gradient of $10 \mathrm{~min}$, ending in $25 \%$ of mobile phase $\mathrm{B}$.

\section{Statistical analysis}

Statistically significant differences between groups were determined by one-way ANOVA followed by a NewmanKeuls post hoc test. Unless otherwise stated, all data is presented as mean \pm SEM for $n=$ eight mice per group. For APAP disposition data, t-test was used for statistical significance. Values with $\mathrm{P} \leq 0.05$ were considered statistically significant. 


\section{Additional files}

Additional file 1: Figure S1. Title of data: Moderate steatosis $\mathrm{db} / \mathrm{db}$ mice. Description of data: Hematoxylin and eosin staining showing mild to moderate steatosis in female and male $\mathrm{db} / \mathrm{db}$ mice as compared to C57BKS mice livers.

Additional file 2: Table S1. Title of data: Primary antibodies for western blot. Description of data: Type, dilution, molecular weight and sources of primary antibodies for western blot.

\section{Abbreviations}

Abc: ATP binding cassette; ADME: Absorption distribution metabolism and elimination; APAP: Acetaminophen; APAP-CG/CYS: Acetaminophen cysteinylglycine/cysteine; APAP-G: Acetaminophen glucuronide; APAPNAC: Acetaminophen N-acetyl L-cysteine; APAP-S: Acetaminophen sulfate; Car: Constitutive androstane receptor; Cyp: Cytochrome P450; DAPI: 4' 6-diamidino-2-phenylindole; DILI: Drug-induced liver injury; DME: Drug metabolizing enzyme; FXR: Farnesoid-X- receptor; Gclc: Glutamate cysteine ligase; HNF1a: Hepatocyte nuclear factor-1a; Icam-1: Intercellular adhesion molecule-1; IL: Interleukin; Mcp: Monocyte chemoattractant protein; Mdr: Multidrug resistance protein; NAFLD: Non-alcoholic fatty liver disease; NASH: Non-alcoholic steatohepatitis; PBS: Phosphate buffered saline; PBS/T: Phosphate buffered saline with Tween 20; Ppar: Peroxisome proliferator activated receptor; PXR: Pregnane-X-receptor; Shp: Small heterodimer partner; ST buffer: Sucrose tris buffer; T1DM: Type-1 diabetes mellitus, T2DM, type-2 diabetes mellitus; TG: Triglycerides; Tnf-a: Tumor necrosis factor-a.

\section{Competing interests}

The authors declare that they have no competing interests.

\section{Acknowledgements}

We thank Dr. Michael Goedken, Dr. Maureen Drisoll and Dr. Jialin Xu for providing valuable inputs in editing the manuscript. We also thank Dr. Michael Goedken for pathological evaluation of $\mathrm{H}$ and $\mathrm{E}$ stained liver and kidney sections. This work was supported by National Institute of Health [1R01ES016042, 1R00DK080774], and also supported, in part, by Rhode Island IDeA Network of Biomedical Research Excellence [Award \# P20RR016457-10] from the National Center for Research Resources, National Institute of Health, National Institute of Health [5K22ES013782], and the Rhode Island Foundation as well as the NIEHS sponsored UMDNJ Center for Environmental Exposures and Disease [P30ES005022].

\section{Author details}

'Department of Biomedical and Pharmaceutical Sciences, University of Rhode Island, Kingston, RI 02881, USA. ${ }^{2}$ Department of Pharmacology and Toxicology, Rutgers University Ernest Mario School of Pharmacy and Environmental and Occupational Health Sciences Institute, Piscataway, NJ 08854, USA. ${ }^{3}$ Department of Chemical Biology, Rutgers University Ernest Mario School of Pharmacy and Environmental and Occupational Health Sciences Institute, Piscataway, NJ 08854, USA.

\section{Authors' contributions}

VRM performed all experiments with mRNA and protein expression and immunohistochemistry, and drafted the manuscript. XW analyzed urine samples for APAP and metabolites. PET developed method for APAP analysis by HPLC. ALS, LMA and VRM designed the experiment, and contributed to writing of manuscript. All authors read and approved the final manuscript.

Received: 19 October 2011 Accepted: 23 April 2012

Published: 23 April 2012

\section{References}

1. Wild S, Roglic G, Green A, Sicree R, King H: Global prevalence of diabetes: estimates for the year 2000 and projections for 2030. Diabetes Care 2004, 27:1047-1053.
2. Chiang DJ, Pritchard MT, Nagy LE: Obesity, diabetes mellitus, and liver fibrosis. Am J Physiol Gastrointest Liver Physiol 2011, 300:G697-G702.

3. Lazo M, Clark JM: The epidemiology of nonalcoholic fatty liver disease: a global perspective. Semin Liver Dis 2008, 28:339-350.

4. Lautamaki R, Borra R, lozzo P, Komu M, Lehtimaki T, Salmi M, Jalkanen S, Airaksinen KE, Knuuti J, Parkkola R, Nuutila P: Liver steatosis coexists with myocardial insulin resistance and coronary dysfunction in patients with type 2 diabetes. Am J Physiol Endocrinol Metab 2006, 291:E282-E290.

5. Erickson SK: Nonalcoholic fatty liver disease. J Lipid Res 2009, 50(Suppl): S412-S416.

6. Lu H, Sun J, Sun L, Shu X, Xu Y, Xie D: Polymorphism of human leptin receptor gene is associated with type 2 diabetic patients complicated with non-alcoholic fatty liver disease in China. J Gastroenterol Hepatol 2009, 24:228-232.

7. Friedman JM, Halaas JL: Leptin and the regulation of body weight in mammals. Nature 1998, 395:763-770.

8. Faroogi IS, O'Rahilly S: Leptin: a pivotal regulator of human energy homeostasis. Am J Clin Nutr 2009, 89:980S-984S.

9. Rabe K, Lehrke M, Parhofer KG, Broedl UC: Adipokines and insulin resistance. Mol Med 2008, 14:741-751.

10. Shifflet A, Wu GY: Non-alcoholic steatohepatitis: an overview. J Formos Med Assoc 2009, 108:4-12

11. Hummel KP, Dickie MM, Coleman DL: Diabetes, a new mutation in the mouse. Science 1966, 153:1127-1128.

12. Uchida T, Nakamura T, Hashimoto N, Matsuda T, Kotani K, Sakaue H, Kido Y, Hayashi Y, Nakayama KI, White MF, Kasuga M: Deletion of Cdkn1b ameliorates hyperglycemia by maintaining compensatory hyperinsulinemia in diabetic mice. Nat Med 2005, 11:175-182.

13. Yamauchi T, Nio Y, Maki T, Kobayashi M, Takazawa T, Iwabu M, Okada-Iwabu M, Kawamoto S, Kubota N, Kubota T, et al: Targeted disruption of AdipoR1 and AdipoR2 causes abrogation of adiponectin binding and metabolic actions. Nat Med 2007, 13:332-339.

14. Cheng Q, Aleksunes LM, Manautou JE, Cherrington NJ, Scheffer GL, Yamasaki H, Slitt AL: Drug-metabolizing enzyme and transporter expression in a mouse model of diabetes and obesity. Mol Pharm 2008, 5:77-91.

15. Klaassen $C D$, Aleksunes $L M$ : Xenobiotic, bile acid, and cholesterol transporters: function and regulation. Pharmacol Rev 2010, 62:1-96.

16. Hagenbuch B, Gui C: Xenobiotic transporters of the human organic anion transporting polypeptides (OATP) family. Xenobiotica 2008, 38:778-801.

17. Brandoni A, Torres AM: Characterization of the mechanisms involved in the increased renal elimination of bromosulfophthalein during cholestasis: involvement of Oatp1. J Histochem Cytochem 2009, 57:449-456.

18. Corcoran GB, Wong BK: Obesity as a risk factor in drug-induced organ injury: increased liver and kidney damage by acetaminophen in the obese overfed rat. J Pharmacol Exp Ther 1987, 241:921-927.

19. Lickteig AJ, Fisher CD, Augustine LM, Aleksunes LM, Besselsen DG, Slitt AL, Manautou JE, Cherrington NJ: Efflux transporter expression and acetaminophen metabolite excretion are altered in rodent models of nonalcoholic fatty liver disease. Drug Metab Dispos 2007, 35:1970-1978

20. Corcoran GB, Salazar DE, Chan HH: Obesity as a risk factor in drug-induced organ injury. III. Increased liver and kidney injury by furosemide in the obese overfed rat. Toxicol Appl Pharmacol 1989, 98:12-24.

21. Corcoran GB, Salazar DE: Obesity as a risk factor in drug-induced organ injury. IV. Increased gentamicin nephrotoxicity in the obese overfed rat. J Pharmacol Exp Ther 1989, 248:17-22.

22. Barshop NJ, Capparelli EV, Sirlin CB, Schwimmer JB, Lavine JE: Acetaminophen pharmacokinetics in children with nonalcoholic fatty liver disease. J Pediatr Gastroenterol Nutr 2011, 52:198-202.

23. Cheng X, Maher J, Chen C, Klaassen CD: Tissue distribution and ontogeny of mouse organic anion transporting polypeptides (Oatps). Drug Metab Dispos 2005, 33:1062-1073.

24. Maher JM, Aleksunes LM, Dieter MZ, Tanaka Y, Peters JM, Manautou JE, Klaassen CD: Nrf2- and PPAR alpha-mediated regulation of hepatic Mrp transporters after exposure to perfluorooctanoic acid and perfluorodecanoic acid. Toxicol Sci 2008, 106:319-328.

25. Zamek-Gliszczynski MJ, Nezasa K, Tian X, Bridges AS, Lee K, Belinsky MG, Kruh GD, Brouwer KL: Evaluation of the role of multidrug resistanceassociated protein (Mrp) 3 and Mrp4 in hepatic basolateral excretion of sulfate and glucuronide metabolites of acetaminophen, 
4-methylumbelliferone, and harmol in Abcc3-/- and Abcc4-/- mice. J Pharmacol Exp Ther 2006, 319:1485-1491.

26. Slitt AL, Cherrington NJ, Maher JM, Klaassen CD: Induction of multidrug resistance protein 3 in rat liver is associated with altered vectorial excretion of acetaminophen metabolites. Drug Metab Dispos 2003, 31:1176-1186

27. Xiong H, Suzuki H, Sugiyama Y, Meier PJ, Pollack GM, Brouwer KL: Mechanisms of impaired biliary excretion of acetaminophen glucuronide after acute phenobarbital treatment or phenobarbital pretreatment. Drug Metab Dispos 2002, 30:962-969

28. Court MH: Acetaminophen UDP-glucuronosyltransferase in ferrets: species and gender differences, and sequence analysis of ferret UGT1A6. J Vet Pharmacol Ther 2001, 24:415-422.

29. Coughtrie MW: Sulfation through the looking glass-recent advances in sulfotransferase research for the curious. Pharmacogenomics J 2002, 2:297-308.

30. Lam JL, Jiang $Y$, Zhang $T$, Zhang $E Y$, Smith BJ: Expression and functional analysis of hepatic cytochromes $\mathrm{P} 450$, nuclear receptors, and membrane transporters in 10- and 25-week-old db/db mice. Drug Metab Dispos 2010, 38:2252-2258.

31. Hagenbuch $B$, Meier PJ: The superfamily of organic anion transporting polypeptides. Biochim Biophys Acta 2003, 1609:1-18.

32. Hagenbuch B, Meier PJ: Organic anion transporting polypeptides of the OATP/ SLC21 family: phylogenetic classification as OATP/ SLCO superfamily, new nomenclature and molecular/functional properties. Pflugers Arch 2004, 447:653-665.

33. Cheng X, Maher J, Dieter MZ, Klaassen CD: Regulation of mouse organic anion-transporting polypeptides (Oatps) in liver by prototypical microsomal enzyme inducers that activate distinct transcription factor pathways. Drug Metab Dispos 2005, 33:1276-1282.

34. Cheng X, Klaassen CD: Critical role of PPAR-alpha in perfluorooctanoic acid- and perfluorodecanoic acid-induced downregulation of Oatp uptake transporters in mouse livers. Toxicol Sci 2008, 106:37-45.

35. Memon RA, Tecott LH, Nonogaki K, Beigneux A, Moser AH, Grunfeld C, Feingold KR: Up-regulation of peroxisome proliferator-activated receptors (PPAR-alpha) and PPAR-gamma messenger ribonucleic acid expression in the liver in murine obesity: troglitazone induces expression of PPARgamma-responsive adipose tissue-specific genes in the liver of obese diabetic mice. Endocrinology 2000, 141:4021-4031.

36. Yang ZX, Shen W, Sun H: Effects of nuclear receptor FXR on the regulation of liver lipid metabolism in patients with non-alcoholic fatty liver disease. Hepatol Int 2010, 4:741-748.

37. Maeda T, Miyata M, Yotsumoto T, Kobayashi D, Nozawa T, Toyama K, Gonzalez FJ, Yamazoe Y, Tamai I: Regulation of drug transporters by the farnesoid X receptor in mice. Mol Pharm 2004, 1:281-289.

38. Klaassen $C D$, Slitt AL: Regulation of hepatic transporters by xenobiotic receptors. Curr Drug Metab 2005, 6:309-328.

39. Urquhart BL, Tirona RG, Kim RB: Nuclear receptors and the regulation of drug-metabolizing enzymes and drug transporters: implications for interindividual variability in response to drugs. J Clin Pharmacol 2007, 47:566-578.

40. Rizwan AN, Burckhardt G: Organic anion transporters of the SLC22 family: biopharmaceutical, physiological, and pathological roles. Pharm Res 2007, 24:450-470.

41. Ogasawara K, Terada T, Asaka J, Katsura T, Inui K: Hepatocyte nuclear factor-4\{alpha\} regulates the human organic anion transporter 1 gene in the kidney. Am J Physiol Renal Physiol 2007, 292:F1819-F1826.

42. Saji T, Kikuchi R, Kusuhara H, Kim I, Gonzalez FJ, Sugiyama Y: Transcriptional regulation of human and mouse organic anion transporter 1 by hepatocyte nuclear factor 1 alpha/beta. J Pharmacol Exp Ther 2008, 324:784-790.

43. Kruh GD, Belinsky MG: The MRP family of drug efflux pumps. Oncogene 2003, 22:7537-7552.

44. Toyoda Y, Hagiya Y, Adachi T, Hoshijima K, Kuo MT, Ishikawa T: MRP class of human ATP binding cassette $(A B C)$ transporters: historical background and new research directions. Xenobiotica 2008, 38:833-862.

45. Rius M, Nies AT, Hummel-Eisenbeiss J, Jedlitschky G, Keppler D: Cotransport of reduced glutathione with bile salts by MRP4 (ABCC4) localized to the basolateral hepatocyte membrane. Hepatology 2003, 38:374-384.
46. Rius M, Hummel-Eisenbeiss J, Hofmann AF, Keppler D: Substrate specificity of human ABCC4 (MRP4)-mediated cotransport of bile acids and reduced glutathione. Am J Physiol Gastrointest Liver Physiol 2006, 290:G640-G649.

47. Reisman SA, Csanaky IL, Aleksunes LM, Klaassen CD: Altered disposition of acetaminophen in Nrf2-null and Keap1-knockdown mice. Toxicol Sci 2009, 109:31-40.

48. Aleksunes LM, Campion SN, Goedken MJ, Manautou JE: Acquired resistance to acetaminophen hepatotoxicity is associated with induction of multidrug resistance-associated protein 4 (Mrp4) in proliferating hepatocytes. Toxicol Sci 2008, 104:261-273.

49. Nowicki MT, Aleksunes LM, Sawant SP, Dnyanmote AV, Mehendale HM Manautou JE: Renal and hepatic transporter expression in type 2 diabetic rats. Drug Metab Lett 2008, 2:11-17.

50. Weiss J, Sauer A, Herzog M, Boger RH, Haefeli WE, Benndorf RA: Interaction of thiazolidinediones (glitazones) with the ATP-binding cassette transporters P-glycoprotein and breast cancer resistance protein. Pharmacology 2009, 84:264-270.

51. Menees SB, Anderson MA, Chensue SW, Moseley RH: Hepatic injury in a patient taking rosiglitazone. J Clin Gastroenterol 2005, 39:638-640.

52. Bonkovsky HL, Azar R, Bird S, Szabo G, Banner B: Severe cholestatic hepatitis caused by thiazolidinediones: risks associated with substituting rosiglitazone for troglitazone. Dig Dis Sci 2002, 47:1632-1637.

53. Nissen SE, Wolski K: Effect of rosiglitazone on the risk of myocardial infarction and death from cardiovascular causes. N Engl J Med 2007, 356:2457-2471.

54. Li N, Klaassen CD: Role of liver-enriched transcription factors in the downregulation of organic anion transporting polypeptide 4 (oatp4; oatplb2; slc21a10) by lipopolysaccharide. Mol Pharmacol 2004, 66:694-701.

55. Maher JM, Slitt AL, Callaghan TN, Cheng X, Cheung C, Gonzalez FJ, Klaassen CD: Alterations in transporter expression in liver, kidney, and duodenum after targeted disruption of the transcription factor HNF1alpha. Biochem Pharmacol 2006, 72:512-522.

56. Aleksunes LM, Slitt AL, Maher JM, Dieter MZ, Knight TR, Goedken M, Cherrington NJ, Chan JY, Klaassen CD, Manautou JE: Nuclear factor-E2related factor 2 expression in liver is critical for induction of $\mathrm{NAD}(\mathrm{P}) \mathrm{H}$ : quinone oxidoreductase 1 during cholestasis. Cell Stress Chaperones 2006, 11:356-363.

57. Rolo AP, Palmeira CM: Diabetes and mitochondrial function: role of hyperglycemia and oxidative stress. Toxicol Appl Pharmacol 2006, 212:167-178.

58. Cherrington NJ, Slitt AL, Maher JM, Zhang XX, Zhang J, Huang W, Wan YJ, Moore DD, Klaassen CD: Induction of multidrug resistance protein 3 (mrp3) in vivo is independent of constitutive androstane receptor. Drug Metab Dispos 2003, 31:1315-1319.

59. Chen C, Staudinger JL, Klaassen CD: Nuclear receptor, pregname $X$ receptor, is required for induction of UDP-glucuronosyltranferases in mouse liver by pregnenolone-16 alpha-carbonitrile. Drug Metab Dispos 2003, 31:908-915.

60. Hartley DP, Klaassen CD: Detection of chemical-induced differential expression of rat hepatic cytochrome P450 mRNA transcripts using branched DNA signal amplification technology. Drug Metab Dispos 2000, 28:608-616.

61. Ogawa K, Suzuki H, Hirohashi T, Ishikawa T, Meier PJ, Hirose K, Akizawa T, Yoshioka M, Sugiyama Y: Characterization of inducible nature of MRP3 in rat liver. Am J Physiol Gastrointest Liver Physiol 2000, 278:G438-G446.

doi:10.1186/1476-5926-11-1

Cite this article as: More et al: Severe diabetes and leptin resistance cause differential hepatic and renal transporter expression in mice. Comparative Hepatology 2012 11:1 